\title{
Performance of Commercai Banks of Pakistan in the backdrop of Global Financial Crisis
}

Munawwar Ali Kartio-Ph D Research Scholar ,Department of Economics University of Sindh jamshoro Prof Dr Abida Taherani-Supervisor (Vice Chancellor University of Sindh Jamshoro)

Prof Ghulam Hussain Khaskhelly-Co Supervisor ,SDSC University of Sindh Jamshoro

\section{Abstract}

This research paper highlights the efficiency \& performance of commercial banks of Pakistan after the emergence of global financial crisis. The crisis were basically started in United States after the collapse of subprime mortgage market but engulfed the entire globe though the level of severity was different from country to country. Paper also discusses the challenges and obstacles hindered the smooth performance of banking sector in Pakistan. Five big banks of the country were selected to evaluate their efficiency in terms of profits, liquidity and solvency. For this purpose various financial ratios were used to avoid size disparity of banks. The banks play an important role of financial intermediation; channelize savings of public to investors hence basic key performance indicators for this research were deposits, profit, advances and capital.An attempt has been made to examine the growth and sustainability of banks through their performance from 2007 to 2012 , before and after crisis. The main findings are (I) the profitability was affected adversely (II) Non Performing Loans were increasedsignificantly after tight control and management for several years.(III) It was explored that costly deposits were mobilized to maintain the book size and restore the confidence of depositors and all stake holders. (IV)The stability of the system remained unquestionable due to maintenance of Capital Adequacy Ratio well above the targeted ratio of 8 $\%$ in terms of Basel accord.

Key Words: Global Financial Crisis; CommercialBanks; Deposits; Liquidity; profitability; Non Performing Loans.

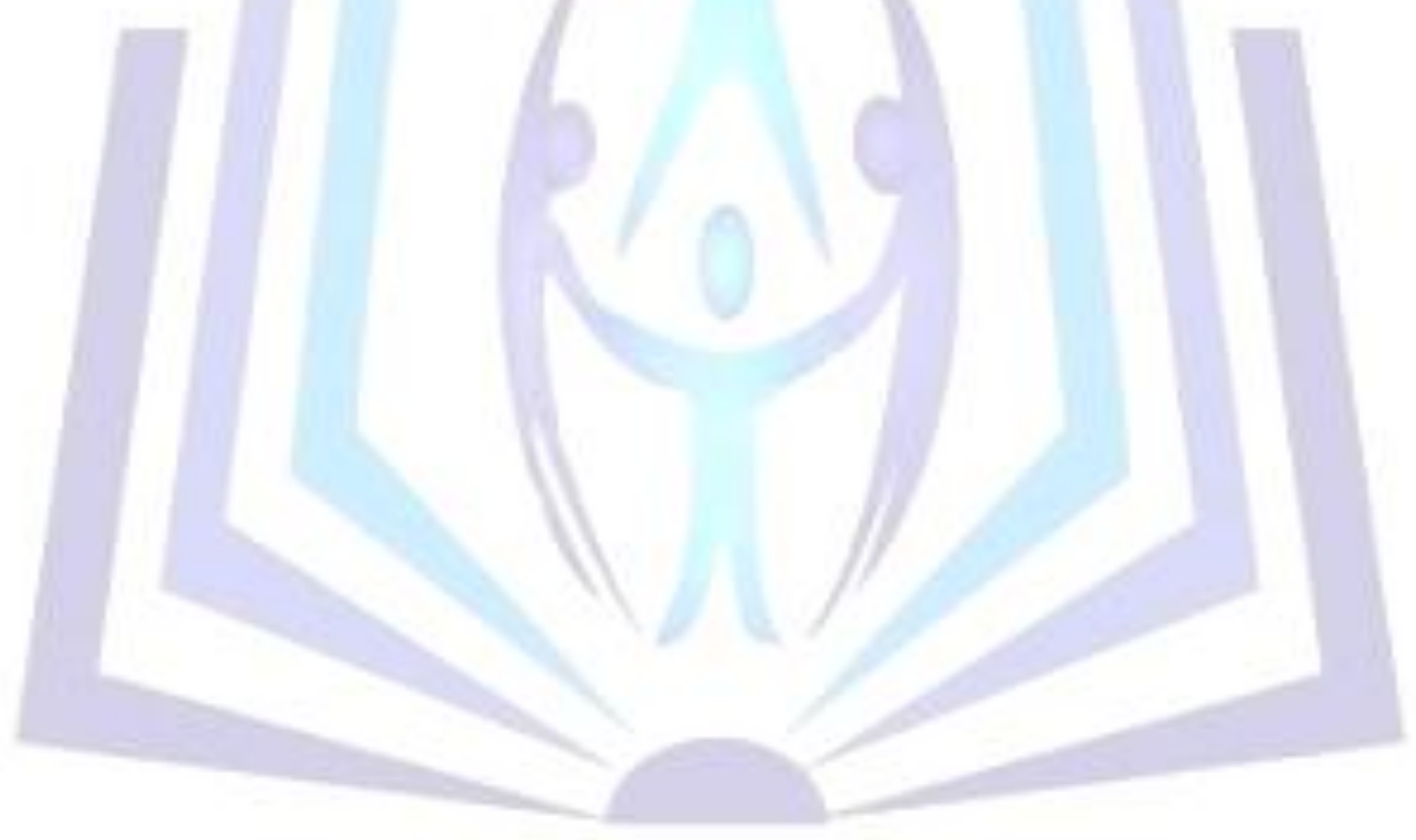

\section{Council for Innovative Research}

Peer Review Research Publishing System

\section{JOURNAL: INTERNATIONAL JOURNAL OF MANAGEMENT \& INFORMATION TECHNOLOGY}

Vol . 11, No .1

editorsijmit@gmail.com

www.ijmit.com 
Introduction The main objective of this research paper is to evaluate the performance of commercial banks of Pakistan in the wake of recent Global Financial Crisis which started in US with collapse of Subprime mortgage market and gripped the entire globe. However the scaleof financial losses varied across the countries. The renowned economists termed it as Great Recession and agreed that severity is more than that of Great Depression of 1930.The crisis is direct result of collapse of house loan industry which was dealing in mortgage loans even extended to those borrowers who otherwise were not eligibledue to bad credit history even in many cases proper verification of documents was not carried out, termed as "liar loans". The study is mainly aimed at to analyze \& evaluate the performance of commercial banks of Pakistan for the period 2007-2012. Specifically, focus is on five well established big banks namely National Bank of Pakistan, Habib Bank Limited, United Bank Limited, and MCB Bank Limited \& Allied Bank Limited. Banks were selected on the basis of their deposits, advances, Stability, profitability, Network, products and services so provided and tenure of presence in the industry. Data were collected from their financial reports. In this age of sophisticated technology and competitive financial market it is very common to use this method of financial ratios to investigate and evaluate performance of Banks.

\section{Causes of Crisis}

The basic and prime cause was imprudent lending for long period of time by ignoring the basic requirements of lending, the credit history and character of borrower, his repaying capacity, fair value of collateral etc. In many cases down payment was relaxed. The role of rating agencies could not be ignored who awarded better rating for financial benefits. An important element was de-regularization, repeal and relaxation of the Glass-Steagall Act of 1933.

\section{Impact of Global Financial Crisis}

The financial crises got extra ordinary impetusin 2007, stock markets of the world witnessed slowdown ,giant financial and insurance institutions collapsed such as Lehman Brothers, American International Group Inc (AIG), Fannie Mae, Freddie Mac etc. Central banks of weak economies such as Ice Land declared bankruptcy and many big banks applied for bailout packages to avoid liquidation.

This caused great recession, severe liquidity issue and credit squeeze in the financial markets. The house prices sharply declined by $20 \%$ from its peak during 2006 and home equity reached at lowest level of $\$ 8.8$ trillion in the mid of 2008 which was valued at $\$ 13$ trillion. In 2009 global output dropped by $2.2 \%$, unemployment increased by $7 \%$ which resulted into more than 35 million people out of job.

\section{Impact of Global Financial Crisis on Pakistan}

A stressedglobal economic down turn hasseized ForeignDirect Investment(FDI) which witnessed a decline by $47.5 \%$ during the period of July 2008 to April2009. Most of this decrease was in the shape of an out flow of private portfolio investment amounting to US\$1 billion.

The import bill of year 2008 was increased due to hike in oil prices in the international market in July 2008. which ultimately raised inflation level and further widened the current account deficit. The import of oil increased by $43 \%$ during $2007-2008$ and touched the figure of US $\$ 10.5$ billion. That was the main reason for increased trade deficit to $\$ 15.3$ billion which was around $57.4 \%$ despite that the exports target of the year $\$ 19.2$ billion was surpassed. This trend further continued for the period July to Oct 2008. The trade deficit was recorded around $\$ 7.55$ billion which was $38 \%$ rise as compared to figure of $\$ 5.47$ billion for the same period of last year. However remittancesmade byoverseas workers' remained stable which were approximately US $\$ 6.4$ billion.During the period under review Pakistan could not raise funds from the capital markets from international markets as entire world was already passing through such unprecedented and extraordinaryrecession.

\section{Overall Impact on Banking Industry in Pakistan}

It is worth mentioning that despite bad governance in Pakistan, Pakistan has a very strong and established banking system particularly after financial sector reforms including privatization of banks and autonomy of State Bank of Pakistan.

In pursuance of demandsfor financial \& economic globalization banking and financial sectors of Pakistan also started to be a part of global financial market.More over one tenths share of deposit in the country was mobilized by foreign banks functioning in the country. Hence the effects and shocks of global financial crisis were also felt though the scale of severity was not as much as observed in developed economies. Keeping in view the rising demands for globalization, banking industry of the country initiated to integrate \& join the global financial markets. Foreign banks also have some concentration in the country which is around one tenth of deposits of banking system in the country as of 2008 . Their presence in Pakistan is escalating the access to loans and financial services, which can promote efficiency \& performance besides better competitive environment within the industry.

Therefore there would have the ripple effect of financial crisis of the west particularly on liquidity and credit contraction on domestic financial sector.

The data on banking sector confirmed slowdown was witnesses in the last quarter of 2008 after multi-year growth. During October 2008 the bank deposits showed a decline to Rs 3.77 trillion as compared to Rs3.67 trillion in Sep 2008. Provisions for bad debts also rose to Rs 178.9 billion from Rs 173 billion in Sep 2008. The interest rates were also raised between 14-20\%. The three months Treasury Bills (TBs) witnessed a rise of 5 per cent approximately (from $9.09 \%$ in Jan 2008 to $14 \%$ in Jan 2009). 
The lending rate is still high, which has made the cost of doing business much higher in the region. The higher lending rate is the direct outcome of the policy interest rate, the maximum in the segment. Monetary growth (M2) was much higher than last year, which creates fears among the economic managers that inflation will once again creep in to the economy and might take the field as it did in financial year 2008 when the inflation was recorded above $20 \%$.

The Non Performing Loans of the banking industry have crossed over 400 billion while the chances of recovery are very much depressing. Non-performing loans has increased significantly which was recorded at $7.4 \%$ to Gross Loans in 2007 and reached at $16.2 \%$ in 2011 the highest one due to rise of interest to discourage lending as a monetary policy tool.

\begin{tabular}{|r|r|r|r|r|r|r|r|}
\hline Year & 2006 & 2007 & 2008 & 2009 & 2010 & 2011 & 2012 \\
\hline $\begin{array}{r}\text { NPL\% of } \\
\text { Gross Loan }\end{array}$ & 7.3 & 7.4 & 9.1 & 12.2 & 14.7 & 16.2 & 14.5 \\
& 7.3 & & & & & & \\
\hline
\end{tabular}

\section{Review of Literature}

There is a lot of empirical literature available on the root causes and the consequences of Financial Crisis and its after effects on banking and global economy.. A number of research reports and publications have been attempted to explore implications and the multi dimensions of Financial Crisis. But a very little or ignorable literature is available regarding its impact on commercial banks in the case of Pakistan on the various financial and operational dimensions.

An attempt has been made to analyze and explore the causes and consequences of Global financial Crisis on various dimensions of economy of Pakistan and performance of commercial banks of Pakistan in terms of profitability, solvency and liquidity.

According to the National Bureau of Economic Research the recent global financial crisis began during December 2007 in the United States due to huge losses on investment made in subprime mortgages (Aubuchon 2009). Immediate upon emergence of crisis entire globe was in grip and great recession has affected adversely the other economies developed or developing. Although this subprime market was the riskiest sector of the home mortgage market and losses were not exempted, it was however the trigger for the severe liquidity crisis in US and worldwide as well (Caballero 200 Morgan et al, 2007, Recent financial crisis started in the mortgage-market of United States when foreclosures and delinquencies on house began to increase dramatically during 2006-2007. The rate of default increased progressively during 2007 and it further accelerated in 2008. The default rates on subprime house loans had originated in 2005 but had broken all the records in 2006 . In 2002 delinquencies reached at the level of 1500 billion US Dollar and in 2004 at the level of 8500 billion US Dollar and climbed to 45500 billion US Dollar in 2007. These mortgage loans were securitized $54 \%$ in $2001 \&$ $75 \%$ during 2007.

According to A.B.Ashcraft and T Schuermnn, et al, 2007 It was the process of securitization which caused such heavy financial crisis particularly CDOs (collateralized debt obligations) and CLO (collateralized loan obligations ), near about 75 $\%$ of subprime loans were passed through securitization.

Dr UmerChapra in his recent research regarding financial crisis he explored and argued that the global financial crisis has severely affected the overall growth of banking sector which was observed very slow and was worst than Great depression of the century and further forecasted that the effects of the recession are long lasting. He further explained on credit problem, he analyzed that more profit means more lending and high leverage was the reason which made excess lending possible and resulted into artificial boom in prices of assets and gave rise in speculative investment and consumption. Such high leverage was difficult to unwind and this vicious cycle of selling ultimately lead to steep decline in prices rather to downturn and outcome was financial crisis.

JP Morgan et al,2006 explored that Mortgage-Backed securities which were highly risk bearing had shown extra ordinary credit expansion after 1998 although theses were started to increase in 70s but were limitedly involved and used in mortgaged business till late 90 s.Sudden rise was the reason of global financial meltdown of 2008 .It touched to US $\$$ 45500 billion in 2007 against the figures of US $\$ 1500$ billion in 2002 , a record growth of US $\$ 44000$ billion in five years around $2933 \%$, Moreover the figures of securitization in \% terms against submortgage loans were $54 \%$ in 2001 and $75 \%$ in 2007.

Lowenstein (2008) observed that regulators and Central Banks could not learn the lessons from past events and thus have allowed repetition of events again and again which recurred in shape of Global Financial crisis which was claimed as failure banks as well as their regulators. It was needed to recognize the importance of early warning signals and tight regulation of financial derivatives was made instead of allowing riskier business behaving in speculative manner and seeking for bailout from government.

\section{Research Methodology}

\section{Ratio Analysis}

In this study Banks' performance have been measured by using ratio analysis technique, the main advantage of this method is to remove disparity based on their size of deposits, advances\& network and brings the banks at par. This 
method was also used by other researchers too such as Ahmed \& Hassan (2007),Sabi(1996) and Chen \&Shimerda (1981).

\section{Financial Analysis by using Ratios}

\section{Profit before Tax Ratio \%}

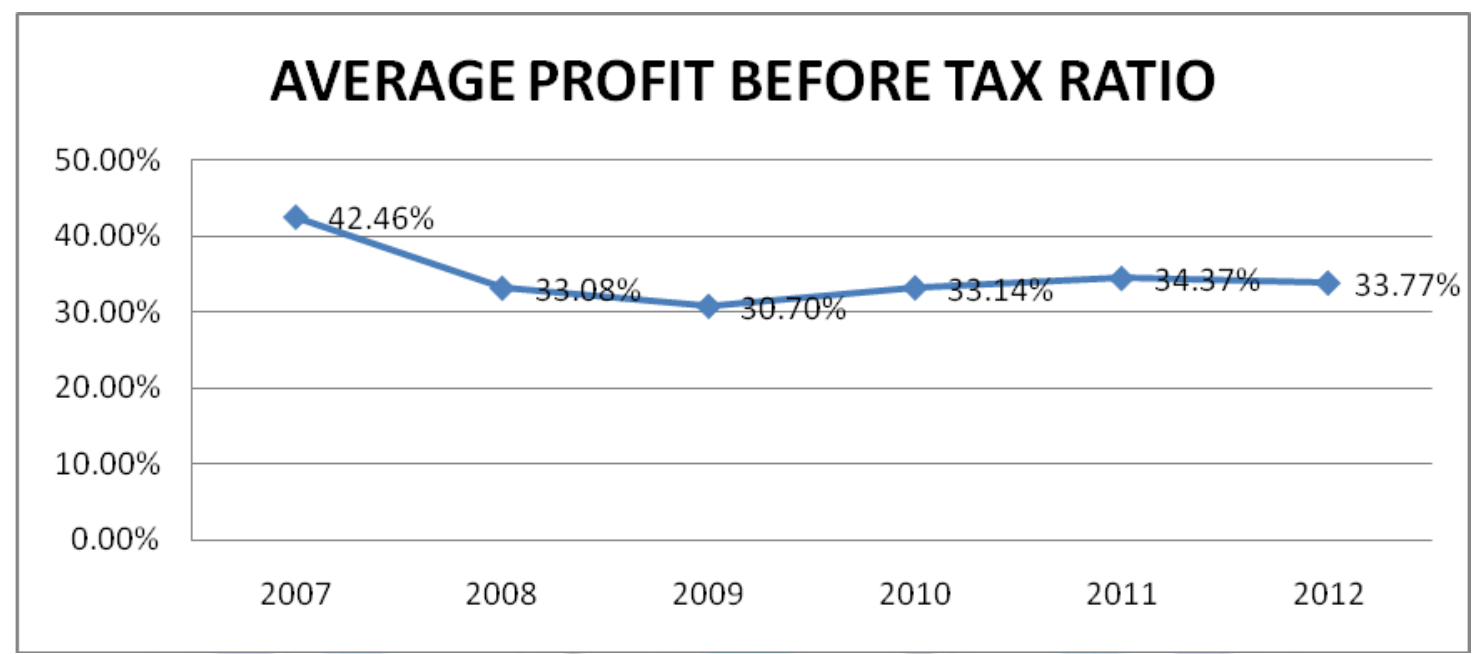

\section{Gross Spread Ratio}

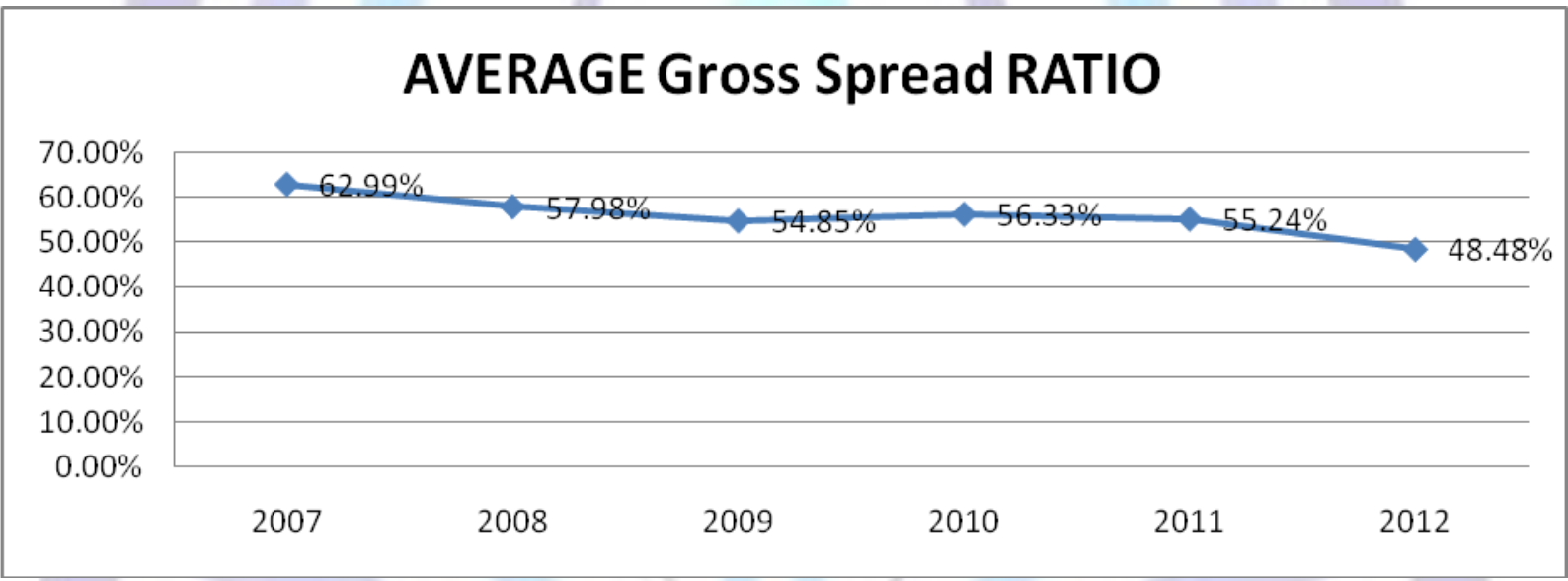

\section{Return on Equity \%}

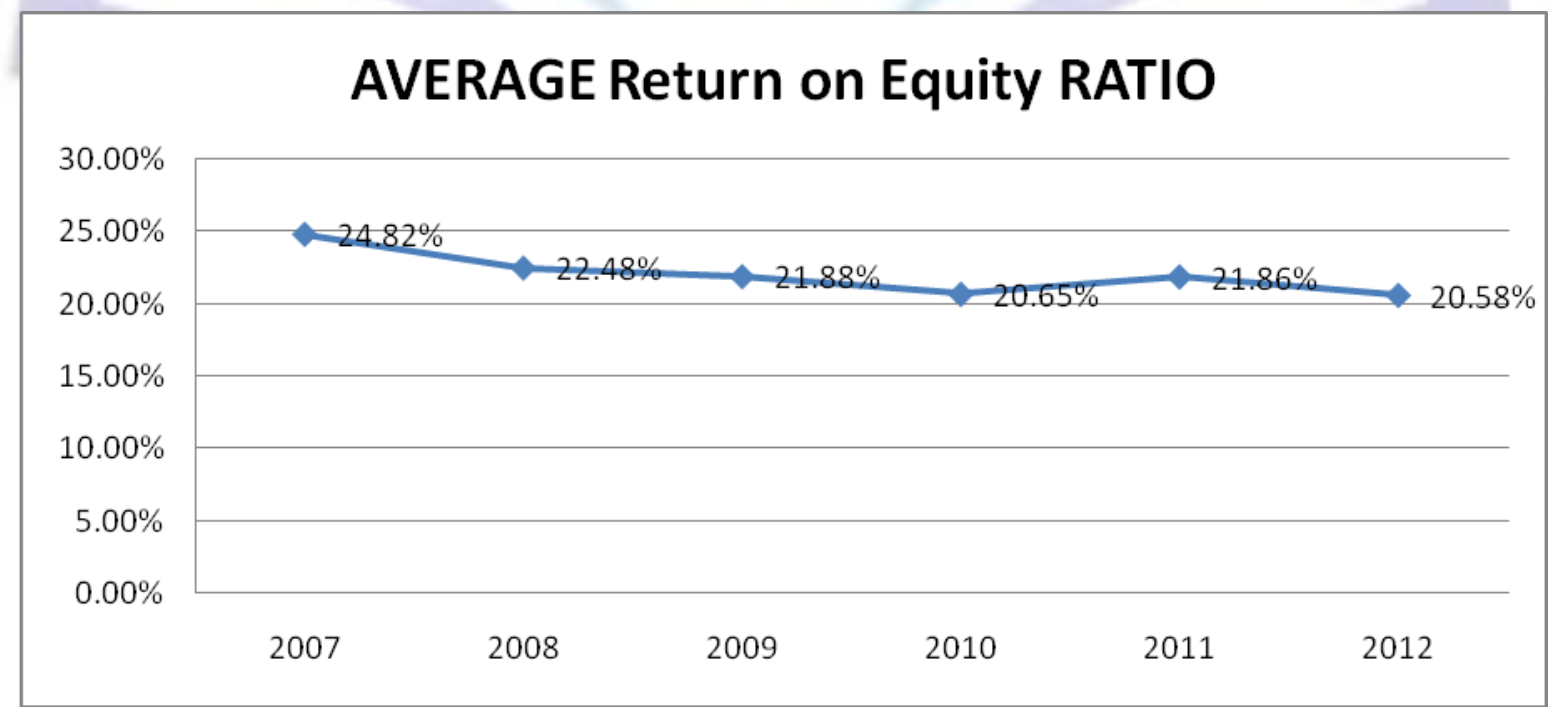


Net Profit to Sales Ratio

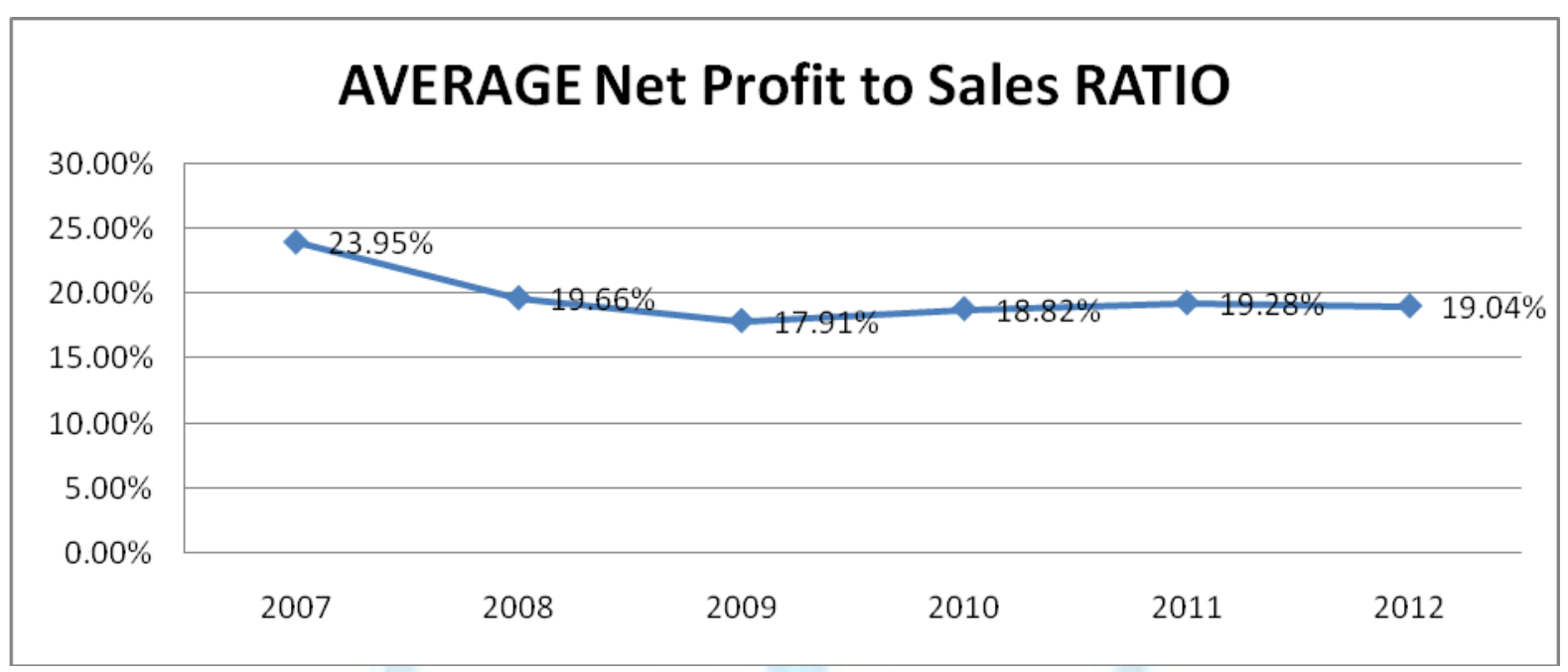

Weighted Average Cost of Deposit \%

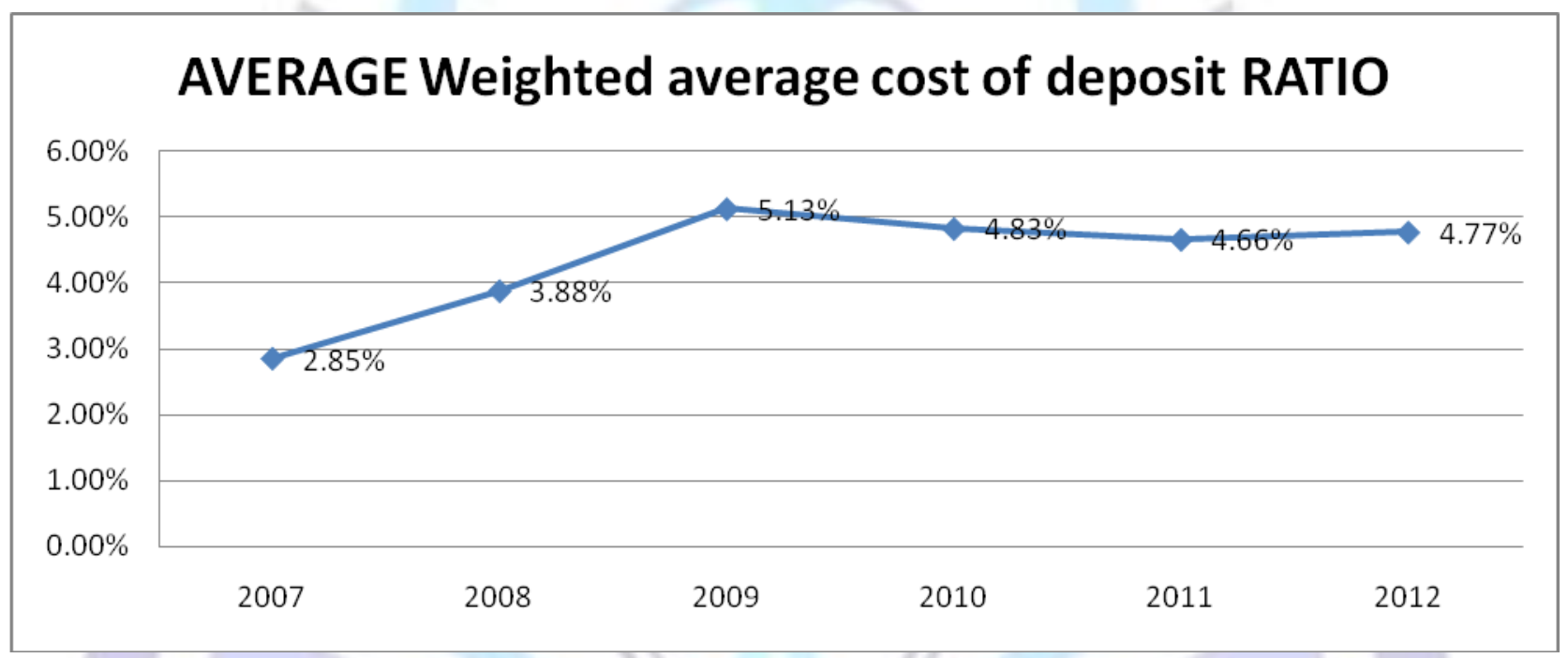

Investment to Deposits Ratio

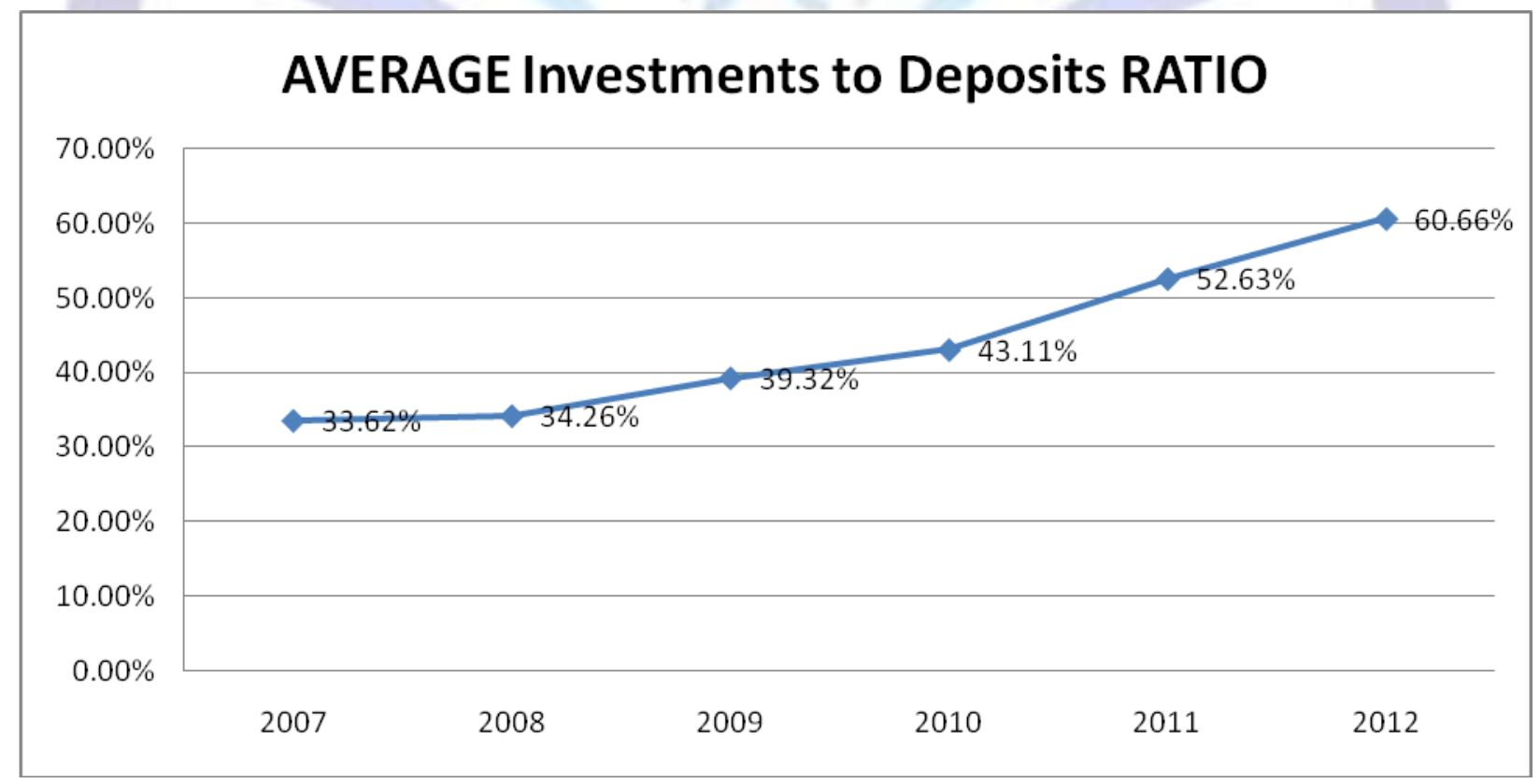


Net Advances to Deposits Ratio \%

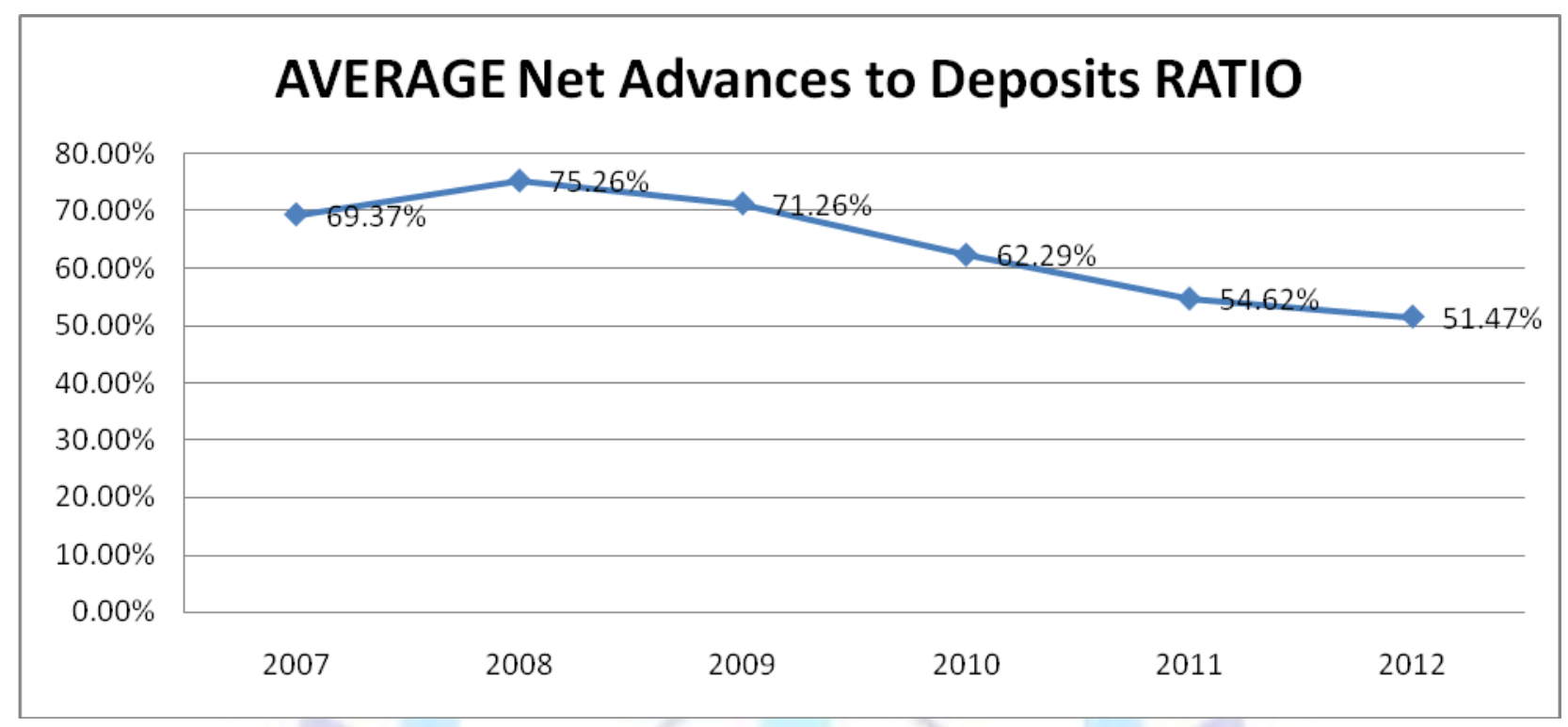

Equity Multiplier Ratio \%

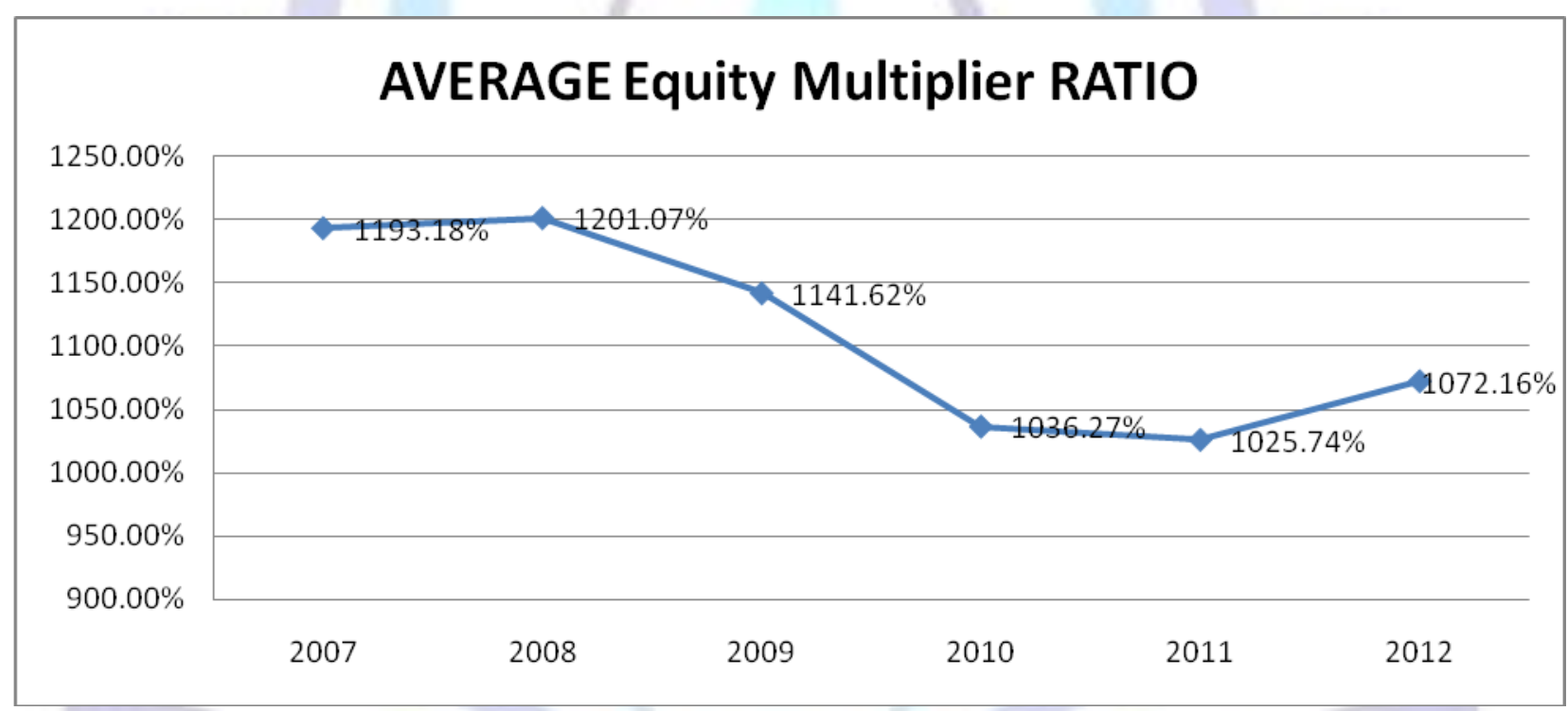

\section{Capital Adequacy Ratio \%}

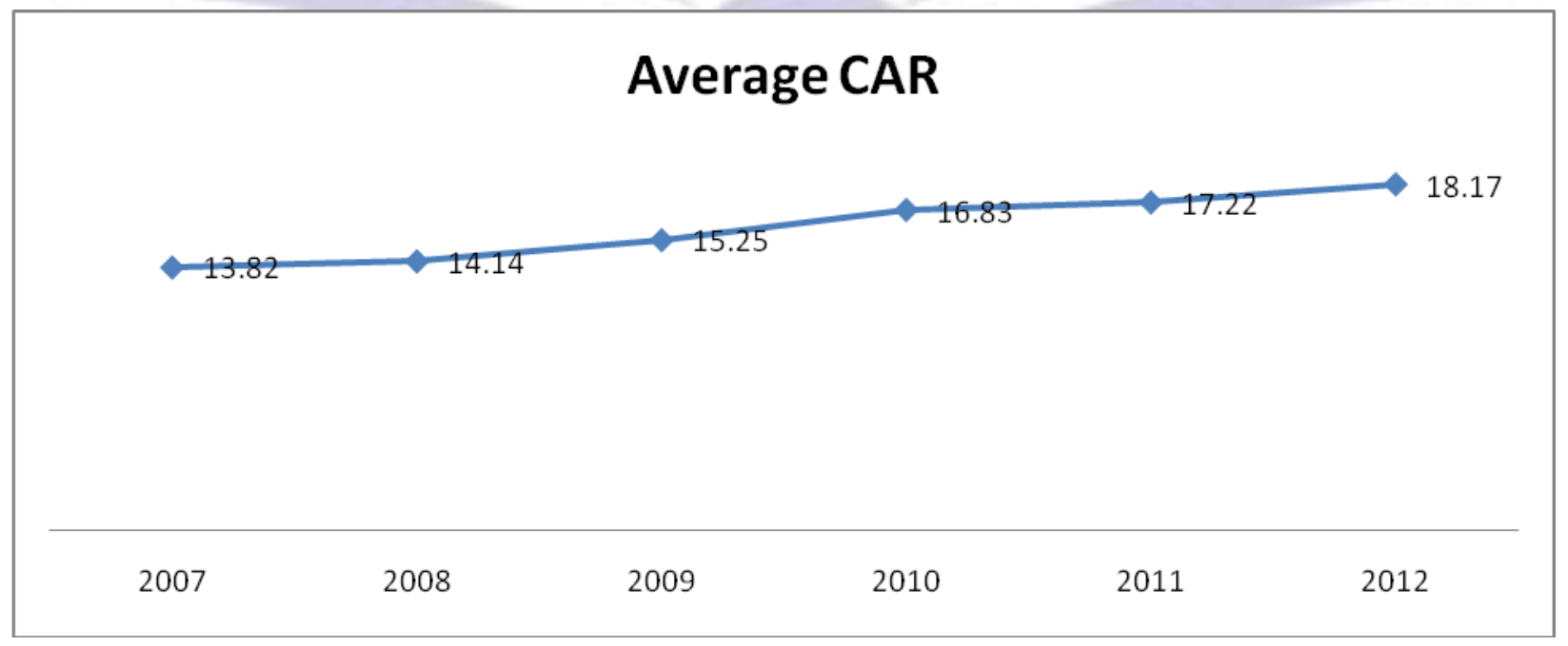




\section{Non Performing Loans \%}

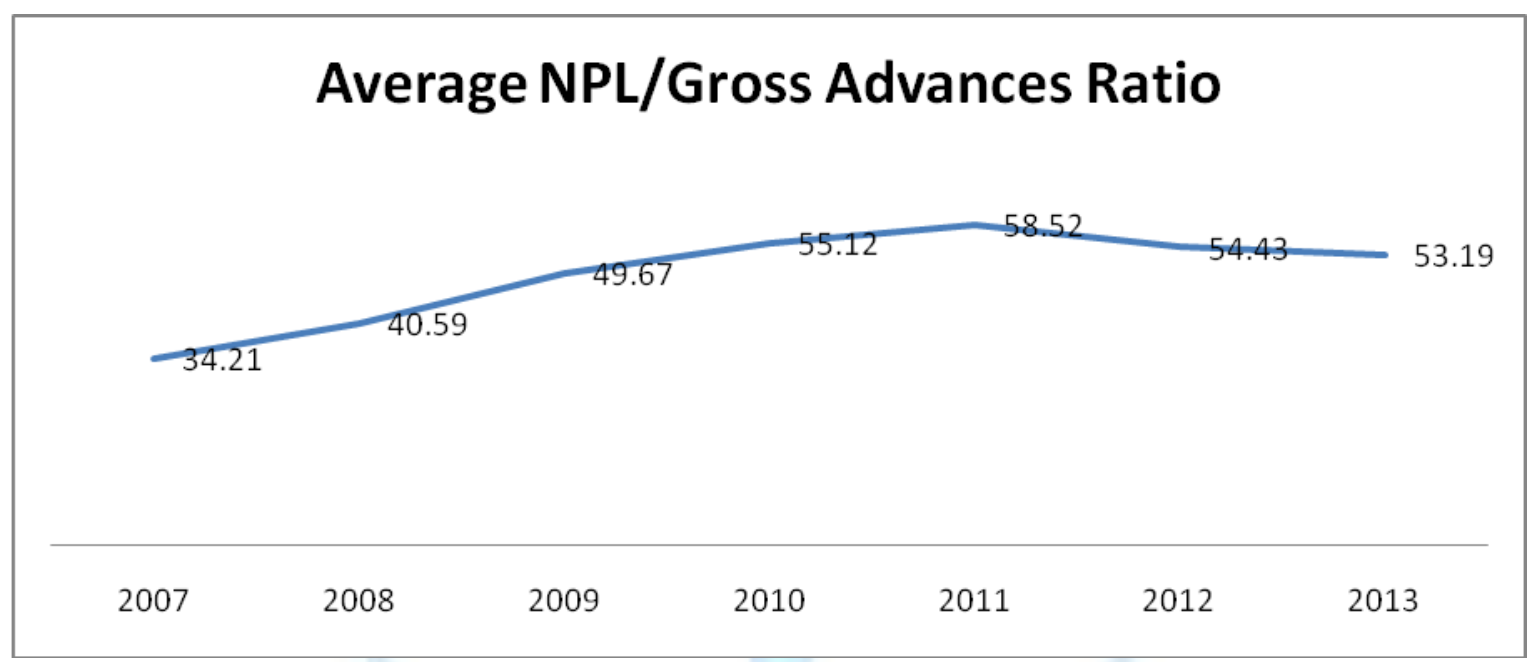

\section{Comments:}

While going through the performance of Banks so far it has been concluded that the sample banks have been adversely affected in terms of profitability. Its Profit before Tax has decreased in terms of Gross Mark up Income due to maintenance of Advances Deposits Ratio which was fixed as $70 \%$.Net Markup income is decreased and Markup expense increased which also reflects from Weighted Cost of deposits.

Return on equity also indicates that equity holders' profitability was reduced significantly. Gross Profit Ratio also confirms Gross profit has been decreased as a result of decrease in Total revenue due to significant increase in cost of Funds/deposits.

Weighted Average Cost of Deposits increased by $71 \%$ in 2009 as compared to base figure of 2007 which clearly depicts that Banks were under pressure to maintain their books and restore confidence in the eyes of stake holders that's why they borne extra cost to mobilize costly deposits.

Advances to Deposits Ratio decreased while investments to Deposits ratio increased which tells that banks focused to invest their funds in treasury bills with safe and steady return and avoided in advances which was not being availed by borrowers due to raise in interest rates.

Gross Advances and Deposits Ratio also confirms liquidity pressure on banks as the advances were increased in comparison to deposits. This ratio also indicates that how a Bank utilizes its deposits by extending loans, relatively low ratio contributes higher liquidity and results in low profits and low ratio creates stress for managing liquidity but higher profits.

Capital Adequacy ratio was well better and shown an increasing trend which tells that there was no issue of solvency at all due to sufficient capital was set aside to safe guard against any loss on assets.

Nonperforming Loans also increased from the highest figure of 2002 which was managed to large extent as at 2007 that shows that counter party failed to meet its obligation (Credit Risk).NPLs to Gross advances ratio also confirms credit risk position prevailed during the period under review it was only due to rise in interest rates, borrowers were unable to meet their obligations.

\section{Primary Data}

Primary Data was collected from management and senior bankers of commercial banks and from of central bank $s$ and customers of banks. A five point Likert scale was used as measurement tool ( 1 for strongly disagree \& 5 for strongly agree).A closed ended questionnaire was developed torecord and analyzing the response of respondents. 


\section{Overall Response-By 371/400 respondents}

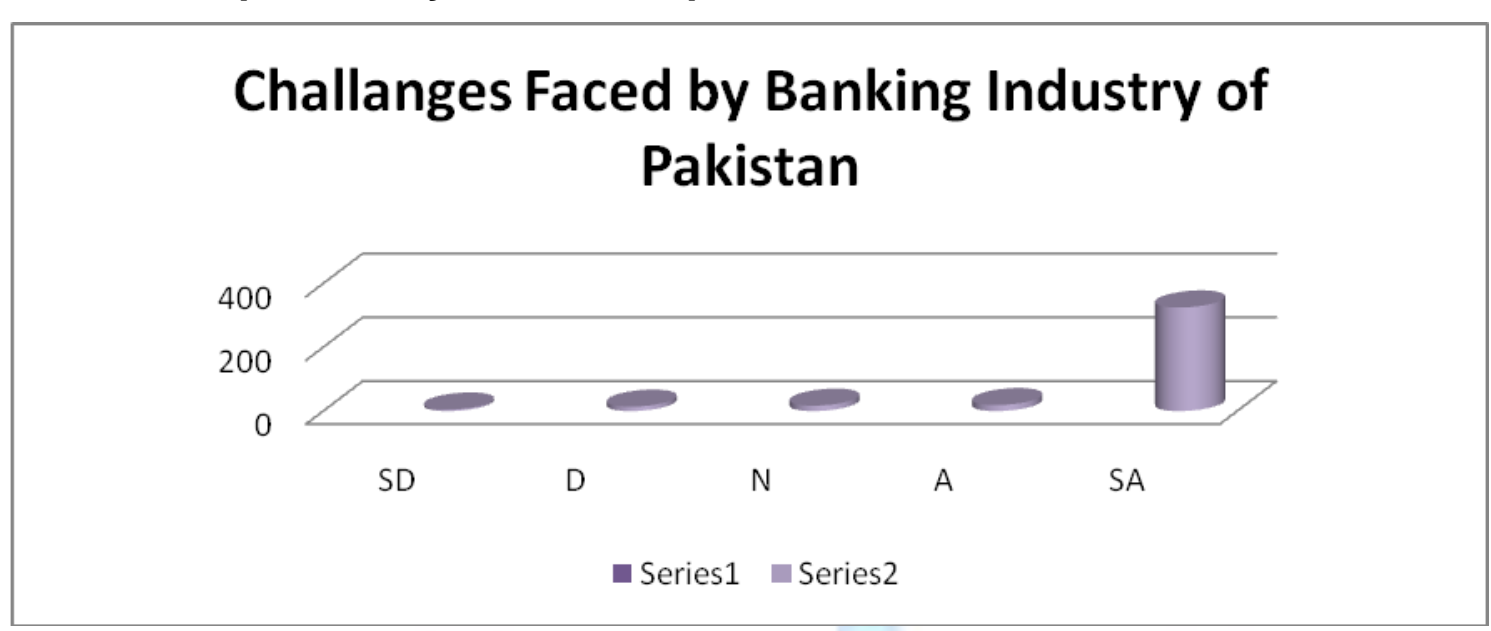

\section{Results}

From survey it is evident that Global Financial crises have negatively impacted the performance of Banking Industry in Pakistan, Cash Reserve Requirement \& Statutory Requirements were relaxed to enable the banks to meet day to day cash requirements, capital flight was occurred, and few banks stopped bonuses and annual increments. Banks diverted from funded income to non funded income by introducing a non core banking product namely Banca assurance etc.

\section{Conclusion}

Thus challenges were Liquidity problem, Accumulation of Bad Loans, Profitability was decreased particularly from Advances and cost of deposit was increased but solvency was strong enough to meet the losses.

\section{Recommendations:}

Monetary policy: More impressive easing of monetary policy is desired. Central bank should take drastic steps to maintain liquidity in US dollar \& domestic markets, lender of last resort facilities may also be used.

\section{Increase monitoring and develop contingency frameworks for systemic financial crisis:}

Although the situations for any major systemic risk have not been developed, yet the Regulator should pay attention and increase vigilance to develop contingency plans to avoid any systemic financial risk. Authorities are required to ensure bank solvency through increased monitoring and formulation of clear policies to deal with strained financial institutions. More over National authorities should clearly indicate that they are closely monitoring the state of affairs and are in standby position to take necessary remedial measures to restore and uphold financial stability.

\section{Increase transparency and risk management}

It is essential to strengthen transparency in financial system. Regulators and federal authorities should ensure and encourage banks to improve more transparency through regular and timely reporting of key performance indicators of profitability, liquidity, and capital, and their exposure to counterparties.

\section{Strengthen bank capitalization:}

Central bank should encourage the financial institutions to raise capital to improve and strengthen their capital ratio above the standards, to strengthen the capital is a clear signal to the financial market that banks \& Financial institutions are entering the downturn from a strong position rather than weak. In the stressed scenario attempt should be made by regulators that systemically strong \& important financial institutions (FIs) would not be allowed to collapse.

\section{Prepare for public purchases of non-performing assets:}

It is also recommended to avoid accumulation of Bad Debts that the assets held by banks against Non-performing loans may be disposed off publically. A mechanism should be in place for government funded companies for purchase of nonperforming securities/assets from financial institutions and banks which will avoid further worsening the economic conditions.

\section{Alleviate a credit crunch}

In the acute situation of a credit crunch, federal regulators should undertake drastic measures to avert a downward spiral to feed into the real sector. Credit can be extended to the real economy directly either through buying financial instrument by the public sector or credit extension by central bank. 


\section{Fiscal policy}

Federal authorities should take notice of backward sectors of economy and should pay attention to increase investment in priority sectors having high growth potential which will change the shape of the economy. Funds may be allocated to those projects which may address the prevailing economic issues like energy crisis, infrastructure and in those sectors having broad based benefits and consistent with environmental improvement, energy conservation and climate change. Banking funds should be utilized on long term economic development project rather on deficit financing.

Rate of Interest: It is recommended that the rates of interest on loans should not be increased during its validity otherwise cost increase may be the cause of repaying capacity and will result into accumulation of unhealthy loans which will adversely affect the profitability and liquidity in banking sector.

Develop Taxation as Public friendly: Government should encourage public to disclose their genuine profits by reducing tax rates so that dual records by business community could be discouraged which will support a transparent culture and bank lending decision will be clearer to avoid Non Performing Loans significantly

Ease financing bottlenecks: In our economy, financing is likely to be a bottleneck for fiscal expansion. It is urged that government should consider ways to facilitate inter country borrowing to finance such spending. Multilateral development banks, bilateral official institutions, and private international financial firms can become involved in issuance, underwriting, credit rating, legal service, among others.

\section{Improve monitoring, surveillance, and regulation:}

The authorities are required for continuous improvement in regulatory supervision of domestic as well as cross-border financial systems to improve the resilience which can help to address those features of regulatory regimes that may have contributed to recent financial turmoil.

Review the role of rating agencies: The role of rating agencies is questionable in the wake of global financial crisis. It is needed to re assess their contribution to the recent financial crisis and a tight mechanism should be placed to ensure that ratings are very fairly awarded and are reliable so that investors can efficiently choose the best available investment opportunities. Rating of rating agencies must be carried out on yearly basis to improve the rating system of agencies and those deviate must be debarred for certain periods.

Role of Chartered Accountants: It should be ensured by regulators that the books of SME and corporate sector are properly prepared and verified by practicing accountants so that genuine need of borrower could properly be assessed. Manipulations of figures may lead to wrong decisions which may ultimately result into excessive lending which will be on stake.

\section{References:}

[1] A. B. Ashcraft and T. Schuermann, "Understanding the Securitization of Subprime Mortgage Credit", FIC Working Paper $n^{\circ}$ 07-43, Wharton Financial Institutions Center, Philadelphia, Pa., 2007.

[2] J.P. Morgan Corporate Quantitative Research, "Credit Derivatives Handbook,", J.P. Morgan, New York, December 2006, p. 6.

[3] Alan Zibel, "'Liar loans' threaten to prolong mortgage crisis" (2008)

[4] Ahmed, O. B. (2001). Islamic Financial Instruments to Manage Short-Term Excess Liquidity (2nd Edition ed.). Jeddah: İlamic Development Bank.

[5] Bartlett, D. (2008) Fallout of the Global Financial Crisis, RSM International Association, accessed on May 2014 at http://www.rsmchina.com.cn/attachments/month_0908/m20098271225.pdf

[6] Charnes, A. Cooper W W and Rhodes E (1978) Measuring Effeciency of Commercial banks with the use of Financial ratios and Data Envelopment Conventional Banks" IIUM Journal of Economics \& Management Vol 10 No 1 pp 1-25

[7] Dar K.H and Shimerda ,T (1981) "An Empirical Analysis of Useful financial ratios " Financial Management Vol10 No 1 pp 51-60

[8] Lowenstein The End of wall Street p.37

[9] Muljawan, D.; H. Dar, and M. J. B. Hall (2002), "A Capital Adequacy Framework for Islamic Banks: The Need to Reconcile Depositors' Risk Aversion with Managers' Risk Taking” ,Loughborough University Economics Papers,

[10] Financial Cycles: What? How? When? StijnClaessens, M. AyhanKose and Marco E. Terrones1 April 2011

[11] Tarawneh, M. (2006), A Comparison of Financial Performance in the Banking Sector: Some Evidence from Omani Commercial Banks. International Research Journal of Finance and Economics, Issue (3). ISSN 1450-2887

[12] WimNaudé. "The Global Economic Crisis and Developing Countries: Effects, Responses and Options for Sustainable Recovery" Poverty \& Public Policy 2.2 (2010): 211. 
[13] Yue, P. (1992), "Data Envelopment Analysis and Commercial Bank Performance: A Prime rwith Applications to Missouri Banks," Working Papers, ICW Institute, University of Texas at Austin.

[14] Zaman, R., \&Movassaghi, H. (2001). Islamic Banking: A Performance Analysis. The Journalof Global Business, 12(22), 31-38. 